\title{
STUCK IN SHARIA SPACE The Experiences of Christian Students in Langsa, Aceh
}

\author{
Yogi Febriandi; Yaser Amri \\ IAIN Langsa, Aceh \\ email:febriandiyogi@gmail.com
}

\begin{abstract}
This article examines the problem of spatial access for Christian students of Samudera University as experiences of minorities in Langsa, Aceh. This article argues that Aceh's public space that is formed by religious identity, leads dichotomy of citizenship in social life. Using life story method, this article explores the problem of Christian students of Samudera University to reside in Langsa. The results show the formation of space by displaying a single identity has polarized majority-minority in public space. Finally, this article also shows that the formation of space by displaying a single identity created an imbalance space for minority, and compelling minority to create alternative space.

[Artikel ini membahas persoalan akses ruang berdasarkan pengalaman mahasiswa minoritas Kristen di Universitas Samudera, Langsa, Aceh. Artikel ini berargumentasi babwa ruang publik. Aceh terbentuk oleh identitas religius yang berujung pada dikotomi kehidupan sosial penduduknya. Dengan pendekatan life story, artikel ini menjelaskan masalah yang dibadapi mahasiswa Kristen yang tinggal di Langsa, Aceh. Dalam kesimpulannya menunjukean bahwa formasi ruang publik terbelah dan tidak seimbang antara identitas mayoritas dan minoritas, dimana identitas minoritas terdesak. untuk menciptakan ruang alternatif baru.]
\end{abstract}

Keywords: Christian students, Sharia space, religious identities, Aceh 


\section{A. Introduction}

This article examines Christian-Muslim relations by focusing on the experience of Christian students to reside in Langsa. Contrary with Asen's, that arguing public space must encourage pluralistic society, we find that the problem of spatial access appeared with many of Christian students registered at Samudera University in $2014 .{ }^{1}$ Most of Christian students come from North Sumatera. As minority in Islamic province, it is not always easy to access public space. Using Lefebvre's theory about dominance space, this article argues that Aceh's public space that is formed by religious identity has polarized majority-minority and leads dichotomy of citizenship in social life.

This article also criticized the cultural perspectives ${ }^{2}$ that encourage pluralistic society to analyze public space. Cultural perspective neglected political domination in public space and does not seen publics competed for domination. ${ }^{3}$ Our study found that majority group dominated the public space in Langsa by limiting Christian minority to the property. In spatial studies, the restrictions on minorities are carried out because the majorities suspect the arrival of minorities who usually come from outside. ${ }^{4}$ Segregation between local community and outsiders in public space resulted in rivalries among communities of faith. ${ }^{5}$ In Abbink's work, the polemics of religious visibility in Ethiopia's public space between Muslim and Christian pay more attention. ${ }^{6}$ Like Abbink, Fisher also shows that the religious polemics nowadays more often about visibility in public

1 Robert Asen, "Ideology, Materiality, and Counterpublicity: William E. Simon and the Rise of a Conservative Counterintelligentsia", Quarterly Journal of Speech, vol. 95, no. 3 (2009), pp. 263-88.

2 Ibid., pp. 263-88; Dolores Hayden, The Power of Place: Urban Landscapes as Public History, 4th edition (Cambridge: The MIT Press, 1997).

${ }^{3}$ Henri Lefebvre, The Production of Space, 1st edition, trans. by Donald NicholsonSmith (Malden, Mass.: Wiley-Blackwell, 1992), p. 7.

4 See Anthony Kwame Harrison, "Black Skiing, Everyday Racism, and the Racial Spatiality of Whiteness", Journal of Sport and Social Issues, vol. 37, no. 4 (2013), pp. 315-39; Ayaka Yoshimizu, "Chopsticks, Phone Bells and Farms: Fuyuko Taira's Diasporic Spatial Practice”, Gender, Place \& Culture, vol. 19, no. 3 (2012), pp. 313-26.

5 Jon Abbink, "Religion in Public Spaces: Emerging Muslim-Christian Polemics in Ethiopia”, African Affairs, vol. 110, no. 439 (2011), pp. 253-74.

${ }^{6}$ Ibid., p. 261. 
space. ${ }^{7}$ Fisher shows that India's public space emerged by the contestation of meaning across diverse language, caste, and religious publics.

The studies of Christians in public space, especially access to residence in Aceh have less attention. The relation of Christian-Muslim in Aceh more often written from the point of view of access to houses of worship, ${ }^{8}$ citizen's studies ${ }^{9}$ and Christian's adaptability in Islamic law. ${ }^{10}$ These works have shown that Christian's life in Aceh has to comply with the Islamic public sphere. In Al Makin's study, it shows that the Christian groups in Aceh even had to submit and let their churches closed since they have no building permit. Furthermore, Ichwan shows that apart from having to comply with the rules for the construction of house of worship, the Christians in Aceh were also treated the status as second class citizens. ${ }^{11}$ In Ansor's study, Christian women in Aceh should make political choices to keep their veil in public or remove it. ${ }^{12}$ Our study of

7 Elaine Fisher, "Public Space, Public Canon: Situating Religion at the Dawn of Modernity in South India", Modern Asian Studies, vol. 52, no. 5 (2018), pp. 1486-541.

8 Al Makin, "Islamic Acehnese Identity, Sharia, and Christianization Rumor: A Study of the Narratives of the Attack on the Bethel Church in Penauyong Banda Aceh", Journal of Indonesian Islam, vol. 10, no. 1 (2016), pp. 1-36.

${ }^{9}$ Moch Nur Ichwan, Arskal Salim, and Eka Srimulyani, "Islam and Dormant Citizenship: Soft Religious Ethno-Nationalism and Minorities in Aceh, Indonesia", Islam and Christian-Muslim Relations, vol. 31, no. 2 (2020), pp. 215-40.

10 See Muhammad Ansor, "Being Woman in the Land of Shari'a: Politics of the Female Body, Piety, and Resistance in Langsa, Aceh", Al-Jami' ab: Journal of Islamic Studies, vol. 52, no. 1 (2014), pp. 59-83; Muhammad Ansor, "We are from the Same Ancestors: Christian-Muslim Relations in Contemporary Aceh Singkil", Al-Albab, vol. 3, no. 1 (2014); Muhammad Ansor, Ismail Fahmi Arrauf, and Yaser Amri, "Under The Shadow of Sharia: Christian Muslim Relations from Acehnese Christian Experience”, KOMUNITAS: International Journal of Indonesian Society and Culture, vol. 8, no. 1 (2016), pp. 125-34; Muhammad Ansor and Cut Intan Meutia, "Jilbab dan Reproduksi Identitas Perempuan Kristen Ruang Publik Sekolah Aceh”, Jurnal Kawistara, vol. 6, no. 2 (2016), pp. 157-74; Muhammad Ansor, “"Menjadi Seperti Beragama Lain': Jilbab dan Identitas Hibrid Mahasiswi Kristen Aceh”, Penamas, vol. 29, no. 1 (2016), pp. 11-30; Muhammad Ansor, "Post-Islamism and the Remaking of Islamic Public Sphere in Post-reform Indonesia", Studia Islamika, vol. 23, no. 3 (2016), pp. 471-515; Abidin Nurdin et al., "The Role of Ulama in the Application of Islamic Syariah in Aceh: A Study of Aceh Ulama Council's Fatwa on Apostasies and Heresies", Mazabib, vol. 17, no. 1 (2018), pp. 46-68.

11 Ichwan, Salim, and Srimulyani, "Islam and Dormant Citizenship", pp. 215-40.

12 Ansor, "Being Woman in the Land of Shari'a". 
Christian students in Langsa shows that the influence of a strong Islamic identity on Christian-Muslim relations in Aceh also affects Christian groups' access to the property (residence). In addition, this study also shows the resistance of Christian students to space restrictions by creating alternative spaces.

To approach the purpose of this study, we used the life story method by following five Christian students of Samudera University Langsa: Va, $\mathrm{Ma}, \mathrm{La}, \mathrm{El}$ and Ni. To get a complete picture of the situation and as a data clarification process, we also interviewed government officials and some people involved in important events, like Mr. Lon, Ms. Wa and Ms. Ti. The life of Christian students observed to describe everyday life and relation among Christian students and Muslim residents. All informants in this article described in the anonymous format. We had agreement with the sources to transcribe their identities with anonymous. This is to maintain the privacy of the informant and provide a sense of security for the information provided by the resource persons in this article.

\section{B. Christian Students under the Space of Sharia}

In this section, we discuss the relationship between Islamic Sharia and political formation of public space. To achieve dominance over space then the state needs to seize the hegemony of space. ${ }^{13}$ Using Lefebvre's perspective, we show that the implementation of Islamic Sharia created a dichotomy of space. ${ }^{14}$ This dichotomy occurs because Sharia Islam becomes an important instrument of the state to construct social life in Aceh. This led to dominating public knowledge of the formation of space. ${ }^{15}$ We argues Islamic Sharia also used to organize social action and the way society responds to space. The production of Islamic Sharia ideas seeps into all forms of social systems, rules and the formation of space.

In order to analyze the dichotomy of space in Aceh, Langsa's public space suit to be observed. Langsa is a center of social, economic and educational activities in eastern Aceh. Therefore, the spread of ethnicity in Langsa more diverse compared to other areas on the east coast of Aceh. In Langsa, most of Christian students reside in Gampong Sidodadi,

13 Abbink, "Religion in Public Spaces", p. 254.

14 Ibid.

15 Fisher, "Public Space, Public Canon", p. 1488. 
Gampong Meurandeh Dayah and Gampong Meurandeh, because these gampongs are quite close to Samudera University Langsa. Main residents of these areas were diverse community. However, that diversity slowly faces the distortions that affected by the domination of government in creating 'Islamic' public space. The construction of identity by government can be viewed in public arena. According to Ansor, Langsa uses raids against clothes, appeal letter and banner to create an Islamic environment. ${ }^{16}$

Because of the politic of creating an 'Islamic' space, religious minorities had significant impact. ${ }^{17}$ In Langsa, we found that Bataknese and Chinese the most disputes access to space because of their religious affiliation. Bataknese is more difficult in gaining access to space not only due to Christian identity, but also because of strong ethnic perceptions in Aceh. Unlike the Chinese people, who were located in the Chinatown region of Teuku Umar Street, Bataknese have more difficulties when trying to reside, especially Bataknese students from North Sumatera. As the time goes by, the Chinese condition was slowly distorted from the public space. At the celebration of Idul Fitri, a group of people lowered lanterns was a form of Idul Fitri celebration in Chinatown residence. However, the lanterns descended after fatwa from the dayah (traditionalist preacher) leader, who told that hooking up lanterns is haram, therefore, should not be visible in public space. Dayah leaders see the lanterns as a symbol of humiliation against Langsa Muslims. In response to this, the Langsa government allowed the unilateral reduction of the lanterns. ${ }^{18}$

Given this case, the author considered that Sharia regulation encouraged 'Islamic' public space. It is important to note that Sharia regulation has been the main factor which changes the Aceh's public space after the reform era, especially after Law 44/1999 has been published. This law became the main legal foundation to form qanun syariat Islam (Sharia regulation) in Aceh. After this regulation, in 2002 Aceh ratified Qanun 11/2002. This Qanun became a powerful instrument of the government in organizing the space because the regulation gave vast

16 Ansor, "Being Woman in the Land of Shari'a", p. 4.

17 Abbink, "Religion in Public Spaces", p. 254.

18 Tgk. Zulkarnain, "Melihat Lampion Secara Holistik", AJNN.net, https:// www.ajnn.net/news/melihat-lampion-secara-holistik/index.html, accessed 9 Aug 2020. 
authority to be in terms of Creed, Worship and Islamic propagation. ${ }^{19}$ Qanun 11/2002 set the space that annexes the public domain of privacy, such as the application of Islamic dress. ${ }^{20}$

A corresponding discussion, the Aceh's public space situation like nowadays is different from the public space before Sharia regulation implemented. In Mr. Lon's memories, when he still a member of HKBP Church Youth in 1990's Langsa has a harmonious public life. The Muhammadiyah mosque and HKBP Church becomes a symbol of harmony between Muslim and Christian communities, because the location of these two houses of worship adjoined. The relation between Muslim youth and HKBP Church youth was so intense before 1990. The choir held every August 17 became the unifier of young Muslims and Christians. In essence, the conditions are change when the conflict has ended and Christian's prejudgment has risen. ${ }^{21} \mathrm{He}$ seems to be sure the impulse of religious figures views became the cause of the residents' objection Church choir sang by Christian youth group. Undoubtedly, today the visibility of Christian's vocal groups in public space became a problem.

The expression of religious minorities that effected social interaction is not only in Langsa. Many scholars have discussed some relevant cases and investigated the problem. For example, Gale and Naylor explored the strong development of religion in Britain has changed the form of social interaction even affected the formation of physical space in Britain. ${ }^{22}$ They argued that the strong religious expression continues to suppress the public space and contributes to changing physical space. This situation also demonstrated in England which is facing the changed of city landscape after appearances of Hindu community in public arena getting stronger. ${ }^{23}$ In Langsa, the Islamization of space is increasingly an

19 R. Michael Feener, Shari'a and Social Engineering: The Implementation of Islamic Law in Contemporary Aceh, Indonesia (Oxford: Oxford University Press, 2014), p. 294.

20 Ansor, "Being Woman in the Land of Shari'a".

21 Mr. Lon, interview (24 Sep 2017).

22 Richard Gale and Simon Naylor, "Religion, Planning and the City: The Spatial Politics of Ethnic Minority Expression in British Cities and Towns", Ethnicities, vol. 2, no. 3 (2002), pp. 387-409.

23 Ibid. 
intense argument, when in 2014 Samudera University accepted Christian students through a state acceptance channel (SNMPTN). According to $\mathrm{Va}$, the number of students who register almost 600 registrants, but just 300 pass. ${ }^{24}$ However, this number is still arguable because no official data from the university found. Still this is a large number, and became serious issue to local residents.

The relationship between Christian students and local residents is not quite good. For that, Mr. Lon's house and Ms. Ti's food stall plays a significant role to help Christian students of Samudera University when they get trouble with the local residents. Mr. Lon's house is close to Samudera University, it is on the same road. Mr. Lon's house has a large courtyard with one main house, and 10 elongated rooms and these rooms are for rent. Since 2014, Mr. Lon's house accepted Christian female students to reside in this house. This decision was taken after hearing numerous reports that female Christian students had difficulty in finding house to reside.

Ms. Ti's food stall is right in front of Mr. Lon's house and the location is on the edge of the intersection road, which connects Gampong Sidodadi, Gampong Meurande Dayah, and Gampong Meurande. Ms. Ti's food stall is place for Christian students to have breakfast, lunch and dinner. Ms. Ti's food stall is quite familiar among Christian students in Langsa. Ms. Ti is a Javanese and Muslim, but the close relationship of Ms. Ti and Christian students is clearly apparent, so it is not surprisingly to listen to Bataknese languages in Ms. Ti's food stall.

Indeed, most of the population in this gampong are Javanese in ethnic. The number of Acehnese is small because most of these areas is oil palm plantations inhabited by diverse people, but mostly are javanese. The Acehnese are more concentrated in coastal areas. Similarly, the religious culture of the gampongs initially did not show exclusiveness to other religions. However, since the increasing number of students entering Samudera University and State Institute of Islamic Studies (IAIN) of Langsa the residents from East Aceh and Aceh Tamiang reside in this area. This made the fantastic growth and more diverse residents. Some residents affiliate to transnational sect like Salafism also increased in number, who rapidly filled the congrational prayer in the mosque. In

24 Va, interview (5 Apr 2017). 
addition, Dayah who have a traditional-militant-looking tendency began to oversee the region. The teachings of the Dayah also began to introduce. This led to contestation between traditionalist and transnationalist.

The contest of these groups makes the space (Mosque, street, shop and university) continuously trapped into the formation of Islamic space. ${ }^{25}$ Under Ojo's work, we see that the situation of Christian students in Langsa is under the same contestation. This is because the Christian students reside in the intersection of contested area. The location of Samudera University is in Gampong Meurandeh, which is situated exactly 20 meters from Mr. Lon's Houses. Right behind Ms. Ti's food stalls, there is a musholla (small mosque) often used by the local residents. Next to the Musholla there is a hallway leading to the homes that many students occupy, including Christian students. Undoubtedly, this situation contributes to exclusive attitude toward Christians. This condition makes Christian students as a minority confined in the struggle for space hegemony.

In that situation, the residents responded to the presence of Christian students with a fears and prejudice. This condition also caused a spread of rumors among the residents, that the presence of Christian students in Langsa as an attempt to build the Church. This news spread rapidly and made the situation of Christian students into the main spotlight. Even the Gampong Sidodadi apparatus made a report to the government regarding the presence of Christian students in their neighborhoods. In responds to Gampong Meurandeh, the government coordinated with Samudera University ensured that Christian students, especially women, were not permitted to participate in the youth groups at late night.

Moreover, the residents of Gampong Meurandeh put the information board/banner with notes that their houses is not for rent to non-Muslim students. Not all houses make such statements, only the houses that rent out the boardinghouses. However, the attitude of rejection felt by the Christian students. This case will be discussed in other section of this article.

25 Matthews A. Ojo, "Pentecostal Movements, Islam and the Contest for Public Space in Northern Nigeria", Islam and Christian-Muslim Relations, vol. 18, no. 2 (2007), p. 176. 


\section{Claiming Islamic Identity}

In this section, we show the resistance of the Muslim residents in accepting Christian students. In describing the resistance, we analyze the increasing number of boards with picture of Muslim women wearing headscarves and sentences that accepts only Muslims. Thomsen argues the condition of minorities in the public space, which prone to neglect, isolation, and even cultural violence. ${ }^{26}$ This condition is caused by an effort to limit access to open space to minorities. In Langsa, we found the Muslim residents as much as possible restricted the existence of Christians by limiting space. This restriction initially runs through social space and then slowly affects the physical space. To protect public space from minority, the Sub-district of Langsa Lama disallows residents to sell their properties to non-Muslims, especially Christians. ${ }^{27}$

In Nejad's work, He shows the conditions of Dezfoul's public space not much different from Langsa. ${ }^{28}$ Nejad shows the ritual of Ashura was transform into a social space in Dezfoul. This transformation also changed the structure of buildings in Dezfoul. In Langsa, the restriction of social space has a bad implication to Muslim-Christian social relations. Although social space restriction allows physical touch to be minimized, the potential for space discrimination against Christian students is inevitable. Constraints of access to residence, the limitation of social space even to control of physical space, consciously and unconsciously occur. Officially, restrictions on access to reside ware marked in the poster's statement that received only Muslims in front of the boarding house.

In Lefebvre's thesis, the representation of space is formed by power. By this forms, the representational space determines the strength of the symbols in public space. ${ }^{29}$ The poster statement confirmed that the Langsa public space was formed by the idealization of religion.

${ }^{26}$ Carly Thomsen, "The Post-Raciality and Post-Spatiality of Calls for LGBTQ and Disability Visibility”, Hypatia, vol. 30, no. 1 (2015), p. 151.

27 Sal, interview (28 Sep 2017).

28 Reza Masoudi Nejad, "The Discursive Manifestation of Past and Present Through the Spatial Organization of the Ashura Procession", Space and Culture, vol. 16, no. 2 (2013), pp. 133-60.

29 Lefebvre, The Production of Space, p. 50. 
The growth of boarding houses in Gampong Sidodadi, Gampong Meurandeh Dayah and Gampong Meurandeh continued to display the space restrictions between Muslims and Christians. The owner of the boarding house does not accept the presence of Christian students due to two main reasons: because the identity of the Christian religion and the stigma of their habits. According to Wa, the stigma has become so attaches.

"They are so dirty. They always throw away used sanitary napkins carelessly. As they consume the pork, their scent refers to unpleasant odors. Moreover, on their gathering their voices while converse is too noisy. Those are girls. The boys are worse. They sing, play guitar, talk loudly and dress immodestly. TI does not like if they live in here, because other tenants would feel uncomfortable. They are Christians, so why should care of them. moreover, we are worry if they stay here, they will make this place as their gathering spot and sing Christian songs like what happened in Mr. Lon's house". ${ }^{30}$

Wa's statements clarify Al Makin's argument about the issue of Christians in Aceh which always under some prejudices. This is because the arrival of Christians in Aceh has always been linked to the issue of Christianization. ${ }^{31}$ Moreover, the issue of the number of Acehnese who converted from Islam to Christianity limited Christian's space. Church activities continued to be watched, both from the day-to-day licensing permit to Church renovation. Not only the activities of worship places, social activities such as the provision of assistance from foreign parties often suspected as an attempt to Christianization. This situation creates a bad prejudice for Christians. Due to this, the spreading news about Christians is no longer by evidence or the truth facts. ${ }^{32}$

Fear is also the basic assumption of Langsa Lama Sub-district staff to continue to monitor the development of the number and activity of Christian students in the gampongs.

"We watched over their movement. We do not want this society having

30 Wa, interview (25 Sep 2017).

31 Makin, "Islamic Acehnese Identity, Sharia, and Christianization Rumor", p. 2.

32 Lucine Endelstein and Louise Ryan, "Dressing Religious Bodies in Public Spaces: Gender, Clothing and Negotiations of Stigma among Jews in Paris and Muslims in London”, Integrative Psychological \& Behavioral Science, vol. 47, no. 2 (2013), p. 257. 
problems because of them. We have often face additional problems due to Christians. For example, Langsa Development Economic (LADEC') was big issue in past years. Their collected support from residents by sharing finance to the residents after the residents gives the copy of their ID card. LADEC affiliated with Christian institution, and they try to distribute the money to the citizens without demanding any return. It must be Christianization projects or Church construction project. Apart from LADEC issue, the problems of worship place spread among residents. The residents inform that there are some Christians who conduct spiritual worship in a house. Both issues develop tension in our place. The next issue is that the coming of Christian students with a large number from Medan. It becomes additional duty for us. The local residents are horrified with such issues". ${ }^{33}$

As a matter of fact, public fears contribute to the condition of public space. The residents and sub-district officers always worry about the emergence of loopholes for Christians to get into their residence. Property such as land, houses, and stores begin to be supervised if the buyer is outsider. To protect their residence from Chirstians spread the sub-district banned selling land or houses to non-Muslims, especially Christians. This prohibition is not clarified in any documents or in any regulation. Lim notes, the ban of selling land or houses to non-Muslim are a convention. These clarify Perkins' argument that space is continuously produces by Islamic symbols to represent Islamic identities in public arena. ${ }^{34}$ According to Lim, this effort is to anticipate Christians spreads which have agenda to build a Church in Langsa.

"Langsa is a comfortable city. This makes the Christians who study at Samudera University feel comfortable. Still more comfortable than Lhokseumawe. The Lhokseumawe citizens are more strict in comparation to langsa. Langsa citizens are heterogen. Therefore, gradually Christians must be willing to buy land in Langsa. Later, the trick they use is not direct Christians who buy land. There are Muslims who replace Christians to buy land. It is common here, that is why we call the Geuchik (village head) if someone wants to buy land. The government always faces that case. The Christians invest land, which seems to be for homes. I believe within ten

33 Oi, interview (20 May 2017).

34 Alisa Perkins, "Muslim Sound, Public Space, and Citizenship Agendas in an American City”, Citizenship Studies, vol. 19, no. 2 (2015), p. 172. 
years when they have enough houses, they propose the establishment of a church. That is the objective. Sidorejo is the target of their objective". ${ }^{35}$

Since many students reside in Meurandeh and Sidodadi, both area change to investment land, especially property business like homes and shops. The price of property in Gampong Sidodadi, Meurandeh Dayah and Meurandeh rose three times in the last five years. According to Wa's, the price of property in Meurandeh and Sidodadi 10 years ago is the cheapest compares with other areas in Langsa. She refused an inheritance of land and house in the Meurandeh region 10 years ago because the land is cheap, but today the price has risen. ${ }^{36}$ In 2014 , the price of 1 hectare is 17 million rupiah, but in 2017, the prices of 1 hectare rise to 75 million.

The establishment of Samudera University and IAIN Langsa in Meurandeh is the main cause of land price arousal in the region. Formerly these three areas were swamp areas, but with the growth of students coming to Langsa, the need for homes increased. Many of the lands that were 10 years ago were still bushes have now turned into two-story buildings. In previous year the houses were far from each other because only few residents living in these gampongs, but now the buildings from permanent to semi-permanent crowded the empty spaces between one house and another.

The consequence of this change is that social space became narrower. People become easy to interact with each other. Meetings are more intense, and sometimes conflicts of ideology accompanies the relationships. In this situation, the state contributes to dominate the space. ${ }^{37}$ This case can be seen when residents besieging Mr. Lon's house to stop the choir practice of Christian students. To resolve mass action, the state approval the wishes of the mass to dispossess Christian students from Mr. Lon's house.

"We are a region that implements Sharia; there is some local wisdom that must be maintained. The government fully supports the implementation of Sharia and maintains the value of local wisdom. We never approve cultural gathering between men and women; Sharia also strictly prohibits the gathering of mixture between men and women in same place. In

\footnotetext{
35 Lim, interview (19 Dec 2017).

36 Wa, interview (25 Sep 2017).

37 Abbink, "Religion in Public Spaces", p. 269.
} 
addition to that, now we have to face Christian students who do not want to wear the hijab. We do not force them, but they should know that Aceh applied Sharia. When they do not practice Sharia, then the residents become unfriendly to them. If I remember the events of last Christmas night, they sing Christian songs and pray in particular house of community member. They should know that such a thing could not be practiced freely here because Aceh has a speciality to implement Sharia". 38

The space shariatization project runs through the presentations, as well as the supervision carried out in the residence. The privilege of Sharia Islam is the basic reason why the government justifies all the actions of the society. The description above shows that the state utilizes Islamic discourse as a tool to dominate public spaces.

\section{Christian Students and the Experience to Reside in Langsa}

In this section, the article focuses on Christian students experience to reside. As shown in the previous section, Christian students not only face the residents who want to minimize the visibility of Christians in public space, but also faces the state. This condition causes Christian students have to adapt to limited space situations. To survive in a public space which intensely rejected Christian visibility, Christian students create alternative spaces to strengthen solidarity and connect with the outside world.

In various discussions and meetings with Christian students in Samudera University, they described their situation as if they stuck in different world. Most of Christian students does not realize that Samudera University is in Aceh, which implemented Sharia Islam. In the process of choosing certain university as destination on SNMPTN, Samudera University is understood as part of USU (University of North Sumatra). Given by SNMPTN information, they thought Samudera University in Medan region, but apparently located in Langsa, Aceh. Many of Christian students disappointed because of incorrect information from SNMPTN. This resulted in Christian students of Samudera University have to struggle for adaptation to Aceh culture, especially to reside and being welcomed in neighborhoods.

38 Sal, interview (28 Sep 2017). 


\section{Struggling to Get a Residence}

The main problem with access to the house is availability of space. This problem can be seen in Meurandeh and Sidodadi too when the numbers of Christian students who entering Samudera University has risen. The SNMPTN is open for the registrants from any place and any background, which resulted in increasing of Christian registrant. However, the unpreparedness of Samudera University and the reaction of residents, make the process of adaptation difficult. According to Va, Christian students have felt difficulty to reside since 2015, a year after transformation of status of Samudera University as private university to state university. ${ }^{39}$ Realizing this, Va took the initiative to form the Christian Student Union in Langsa (Permanas). This idea spreaded among Christian students and become a place to strengthen the solidarity, although currently, only Samudera University who joined Permanas. The use of the word 'Langsa' is a strategy to attract Christians elders outside the campus get involved and contribute to protect the students.

Va was the founder and chairperson of Permanas. He is a Bataknese who grew up in Jakarta. Before coming to Langsa, He lived in Jakarta with his family. Va moves to Langsa because his brother offering him a job in the state-owned palms plantations. In 2011 Va entering Samudera University, when the university was still in private status. He was the only Christian student in his batch. Unlike nowadays, Va have to struggle alone personally. One of his experiences is that it is hard for him to join student council in campus because of his religious affiliation. Va must defend his right in university because other students see Va as a outsider who does not have the same rights as local students.

In 2017, Va is senior student at Samudera University and the oldest 'brother' among Christian students. Nowadays, Va often monitors the daily life of other Christian students. Va and other Christian students created Whatsapp Group and Facebook Group to interact with each other and to update information about situation in Langsa freely without worry being heard by people from outside the community

The main focus of Va's supervision is female students. This is because female Christian student do not wear a headscarf (bijab), and this condition more easily to be ridiculed by Muslim society. Va told that

39 Va, interview (5 Apr 2017). 
he often listen to the gripes of other members. For example, the gripes from $\mathrm{Ma}$ about the difficulties to reside. To resolve Ma's problem, Va had to meet some of the Christian figures in Langsa and convince the residents to accept Christian students. From Ma's stories, Va has so much effort to solve the problem of shelter. Va even had to deal with other residents to find a decent place for Christian students to reside.

"The owner of the place that the boys reside was Victor's friend, so the boys can reside in that house. Before they reside in that place, Va went around to search a house for the boys. However, He was usually rejected because the owner knows that the applicant is Christians. After numerous rejections, the boys decided to rent a room for four people, though the room is actually sufficient only for two persons. The girls condition much worse. They have to live in a room with six partners. However, today, the girls live at Mr Lon's houses, so it is not as crowded as it used to be. Thanks to Va's efforts. Our status is newcomer, in so we still do not know to find safe place to reside". 40

During the struggle to find a place to reside, Va assured the elders of Christian community in Langsa to help and provide accommodation for Christian students who have problem of dwelling. Permanas often used by $\mathrm{Va}$ as a tool to form solidarity between Christians in Langsa to solve the problem of dwelling.

"The reason I created Permanas was for a forum of strengthening solidarity among Christian students who are in diaspora. While in diaspora various problem are inevitable. During this time we have to solve the problem with the assistance of community members since our families are far away from us. So, Permanas is arguably the instrument of our solidarity while in Langsa. In fact, Permanas is not the first of Christian student association in Aceh. In Banda Aceh, there is the Himkus (HMKU) and in Lhokseumawe is HMKL. We annually organize events and meetings in Lhoksemawe ".41

Permanas was created to help Christian students to counter the domination of Islamic public space that was formed by residents and the state. The online group of Permanas members used to counter that dominant space. This online group have weekly meeting schedule. The

\footnotetext{
40 Ma, interview (4 Apr 2017).

41 Va, interview (5 Apr 2017).
} 
discussion group often discussed the situation of Langsa, about the Qanun and the implementation of Sharia, especially the way of anticipating the religious debate with the society. This discussion group used to be conducted in Mr. Lon's house and sometime in HKBP Church. In addition, Permanas also organizes Christian students to join HKBP Church and get involved in various events organized by the Church. The Christian students who are members of Permanas are often invited to cooperate with Langsa HKBP Church in preparing the celebration of the Christian day and Sunday worship.

\section{Limitation for Gathering}

On the Christmas preparations in 2015, a group of people from other residence and local residence pelted Mr. Lon's house with the stones. The people were angry because Mr. Lon let the Christian students gather and sing the Church songs. The people did not like the activity because in their perspective that activity was of worship rituals. I met Mr. Oi to confirm about that incidence, and in our discussion Oi told that the situation could be more dangerous if the Sub-district officer did not come to Mr. Lon's house. In that night, the crowd came and pelted Mr. Lon's house with stones. ${ }^{42}$ After incident, the Christmas night preparations moved to HKBP Church.

According to Va, the number of fellow in Mr. Lons's house at that time were not many because it was only a Christmas song choir exercise. The reason of choosing Mr. Lon's house was because the church location is too far from Christian students domiciles and most of them do not have any ride. Christian students tried informing the residents that their activity was merely an exercise, not worship. However, the residents thought differently and considered the exercise as worship.

"We just practice our choir for the Christmas, but we accused of performing worship illegally. In fact, the worship is not in afternoon or evening. Without knowing what we done, the residents immidiately accused us miscellanously". ${ }^{43}$

Since then the control of residents much stronger to Christians activity in public area. This makes Langsa not too comfortable to

42 Oi, interview (20 May 2017).

43 Va, interview (5 Apr 2017). 
celebrate Christmas and the members decided to celebrate Christmas in Lhokseumawe. In Lhokseumawe Christian student never have bad experience with the people or disturbance by the residents around Church. This is in contrast to Lim's view that Langsa is safe place to Christians. Meanwhile, practically the conditions of religious harmony in Langsa not as good as in Lhokseumawe.

Not too long after that incident, there was another incident where the boys were visited by the youth from Gampong Meurandeh Dayah. They accused that Christian students made other residents feel disturbed. The youths spread the rumors that the male Christian students get drunk and have no manners in dealing with the girls in Gampong Meurandeh Dayah. While according to EL, this suspicion was unreasonable, because the fact was in reverse. The youths of Gampong Meurandeh Dayah are well known for their habit of stealing. The actual reason behind that was the presence of Christian students could endanger their stealing activity. Whatever, El sees all of this happened simply because they are Christians.

\section{E. United Christian Students as Alternative Space}

This section provides an overview of Permanas (United Christian Students) as alternative space which created by Christian students in Langsa. This community was formed to gather solidarity among Christian students. The Permanas was founded in 2015 by Va since the number of Christian students at Langsa increased and it was not matched by the space available for them. There was no room for them to convey their aspirations as well as a little acceptance of them in student organizations which finally encouraged the birth of the Permanas. This community does not have a permanent office or meeting place because it does not get permission from either the University or the village office. Most of the meeting activities are conducted online via Facebook or WhatsApp Group. Apart from that, the meeting was also held at Mr. Lon's house on Saturday. However, the meeting on Saturday was no longer held following protests from residents around Mr. Lon's house. After that the schedule of meetings and venues for meetings is random and not organized.

The meeting at Lon's house was rejected by neighboring because it falls under suspicion that the community is a group that was doing worship. The public asked that the meeting should not be held at Mr. 
Lon's house, and it should be at the University instead. This request was difficult to fulfill because Permanas did not get approval from the University. To anticipate this, Va invited other Christian students to use social media as an alternative for conducting discussions. Utilizing Facebook and WhatsApp, Permanas has become an online community that is widely used by Christian students to form solidarity. The social media influenced the movements and affected the forms of organization that emerge, patterns, and structures of organization. This is in following with Juris' argument that social media bridges the action of protest and communicant in mutually constitutive relation, both via online and offline platform. ${ }^{44}$

In social media, Christian students are free to express themselves and all their opinions, including the discussion of the place for choir. We only had the opportunity to view the contents of Christian student's conversations in social media and was not given access to be part of that virtual community. From the WhatsApp and Facebook Group that we see, the content of the conversation was full of complaints about the situation in Langsa. Va discussed that Whats app Group and Facebook Group are only for Christian students in Samudera University and according to the rules, outsiders are not given permission to join.

This kind of community does not only exist in Langsa. Christian students in Banda Aceh and Lhokseumawe also have similar communities. In Banda Aceh, there is the Unsyah Christian Student Association (HMKU) while in Lhokseumawe, there is the HMKL (Lhokseumawe Christian Student Association). These communities form networks throughout Aceh. This community network builds solidarity as overseas Christian students in Aceh. Usually they meet once a year in December to celebrate Christmas. The meeting location was held in Lhokseumawe with HMKL as the host. The location selection was based on the consideration that Lhokseumawe had a stronger Christian community so that the level of security for carrying out activities was more guaranteed. When compared to Banda Aceh and Lhokseumawe, the Langsa community's acceptance of Christianity is not very good. In Banda Aceh and Lhokseumawe,

44 Jeffrey S. Juris, "Reflections on \#Occupy Everywhere: Social Media, Public Space, and Emerging Logics of Aggregation", American Ethnologist, vol. 39, no. 2 (2012), pp. 259-79. 
there were no cases of difficulty in finding residence. Communities in Banda Aceh and Lhokseumawe have been accustomed with the presence of Christian students since 2005. In contrast with Langsa, which just experienced the increasing presence of Christian students in 2014.

The Permanas, which has been part of this community network since 2016, has been actively participating in joint Christmas celebration in Lhokseumawe. Since the protests of Langsa community, Permanas members moved their big activities to Lhokseumawe. This solidarity is a space for Christian students in Langsa to express their Christian identity. This alternative space was built because there was no freedom for Christian expression in Aceh. In Brown's perspective, hybrid subjectivity in the choreography of encounters, and how related burdens of orchestrating coexistence are shared and struggled over amongst different publics. ${ }^{45}$ This is clear that sharing space between Christian students in Aceh is a way to make alternative space. Space restriction by the community and the state in residential access for Christian students despite showing the form of dominance reacted by the Christian students by creating their own alternative space. This alternative space is used as a space of solidarity and maintains existence as a Christian. This alternative space is then used as a means to survive from the domination of space conducted by Muslims.

This article shows that public space that is formed by religious identity, leads dichotomy of citizenship in social life. From our study in Langsa, the formation of space represents the dominants to exclude the minority from public arena. ${ }^{46}$ This condition provides an illustration that act of restricting Christian students to find a place to reside is existed. However, under certain conditions, Christian students can survive by creating a separate space. ${ }^{47}$ The condition of Christian students who are

45 Katrina M. Brown, "Sharing Public Space Across Difference: Attunement and the Contested Burdens of Choreographing Encounter", Social \& Cultural Geography, vol. 13, no. 7 (2012), pp. 801-20.

46 Hugo Gorringe, "Out of the Cheris: Dalits Contesting and Creating Public Space in Tamil Nadu”, Space and Culture, vol. 19, no. 2 (2016), pp. 164-76.

47 See Luz Marina García Herrera, Ma Carmen Díaz Rodríguez, and Alejandro Armas Díaz, "Social Practices and Gender in a Historic Public Space: The Alameda in Santa Cruz de Tenerife (Canary Islands, Spain)", Urban Research \& Practice, vol. 6, no. 2 (2013), p. 169. 
a minority hardly provides a space of comfort and self-interpretation. However, Christian students create an alternative space to form a solidarity sphere in countering the dominated space.

\section{F. Concluding Remarks}

The findings of this article suggest a model of religious public space, which creates a dichotomy in social life. In public space of Langsa, the dominant citizens resulting communal identity by the use of religion actively. This situation contributes to scarifying other identities. It excludes minority from public space. Using the Lefebvre's production of space, We showed that this situation could be seen in Christian student's experience to reside in Langsa. We argue that the act to ban selling land or houses to non-Muslim is as protection of the social space from others. This study indicates that discrimination of space for Christian students is due to the exclusive space formed by the state. This leads to the rejection of Christian students by the majority of public. The responses of Christian students' to the rejection of their presence lead them to formed alternative space. As I described in this article, alternative space created by strengthening solidarity in both online and offline by linking it to a more inclusive community. Alternative space becomes the strategy of Christian students to stand in limited social space.

Finally, yet importantly, this article not to mention that Sharia Islam project became main factor of Christian student's exclusion in public arena. Various scholars with the main argument that minority exclusion in the public sphere is the desire to dominate the majority have demonstrated the same situation. Therefore, this article cannot generalize the whole picture of the relationship between Muslims and Christians in Aceh, especially relating to the study of the implementation of Islamic policy and pluralism in Aceh. For this reason, further studies are needed which look at the process of strengthening Muslim-Christian religious relations in Aceh. 
Stuck in Sharia Space: The Experiences of Christian Students in Langsa

\section{BIBLIOGRAPHY}

Abbink, Jon, "Religion in Public Spaces: Emerging Muslim-Christian Polemics in Ethiopia", African Affairs, vol. 110, no. 439, 2011, pp. 253-74 [https://doi.org/10.1093/afraf/adr002].

Ansor, Muhammad, "Being Woman in the Land of Shari'a: Politics of the Female Body, Piety, and Resistance in Langsa, Aceh", Al-Jami' ab: Journal of Islamic Studies, vol. 52, no. 1, 2014, pp. 59-83 [https://doi. org/10.14421/ajis.2014.521.59-83].

----, "We are from the Same Ancestors: Christian-Muslim Relations in Contemporary Aceh Singkil", Al-Albab, vol. 3, no. 1, 2014 [https:// doi.org/10.24260/alalbab.v3i1.47].

----, “'Menjadi Seperti Beragama Lain':Jilbab dan Identitas Hibrid Mahasiswi Kristen Aceh", Penamas, vol. 29, no. 1, 2016, pp. 11-30.

----, "Post-Islamism and the Remaking of Islamic Public Sphere in Postreform Indonesia", Studia Islamika, vol. 23, no. 3, 2016, pp. 471-515 [https://doi.org/10.15408/sdi.v23i3.2412].

Ansor, Muhammad, Ismail Fahmi Arrauf, and Yaser Amri, "Under The Shadow of Sharia: Christian Muslim Relations from Acehnese Christian Experience", KOMUNITAS: International Journal of Indonesian Society and Culture, vol. 8, no. 1, 2016, pp. 125-34 [https:/ / doi.org/10.15294/komunitas.v8i1.4966].

Ansor, Muhammad and Cut Intan Meutia, "Jilbab dan Reproduksi Identitas Perempuan Kristen Ruang Publik Sekolah Aceh", Jurnal Kawistara, vol. 6, no. 2, 2016, pp. 157-74 [https:// doi.org/10.22146/ kawistara.15561].

Asen, Robert, "Ideology, Materiality, and Counterpublicity: William E. Simon and the Rise of a Conservative Counterintelligentsia", Quarterly Journal of Speech, vol. 95, no. 3, 2009, pp. 263-88 [https:// doi.org/10.1080/00335630903140630].

Brown, Katrina M., "Sharing Public Space Across Difference: Attunement and the Contested Burdens of Choreographing Encounter", Social \& Cultural Geography, vol. 13, no. 7, 2012, pp. 801-20 [https://doi. org/10.1080/14649365.2012.728614]. 
Endelstein, Lucine and Louise Ryan, "Dressing Religious Bodies in Public Spaces: Gender, Clothing and Negotiations of Stigma among Jews in Paris and Muslims in London", Integrative Psychological \& Behavioral Science, vol. 47, no. 2, 2013, pp. 249-64 [https://doi.org/10.1007/ s12124-012-9228-5].

Feener, R. Michael, Shari'a and Social Engineering: The Implementation of Islamic Law in Contemporary Aceh, Indonesia, Oxford: Oxford University Press, 2014.

Fisher, Elaine, "Public Space, Public Canon: Situating Religion at the Dawn of Modernity in South India", Modern Asian Studies, vol. 52, no. 5, 2018, pp. 1486-541 [https://doi.org/10.1017/ S0026749X17001044].

Gale, Richard and Simon Naylor, "Religion, Planning and the City: The Spatial Politics of Ethnic Minority Expression in British Cities and Towns", Ethnicities, vol. 2, no. 3, 2002, pp. 387-409 [https://doi. org/10.1177/14687968020020030601].

Gorringe, Hugo, "Out of the Cheris: Dalits Contesting and Creating Public Space in Tamil Nadu", Space and Culture, vol. 19, no. 2, 2016, pp. 164-76 [https://doi.org/10.1177/1206331215623216].

Harrison, Anthony Kwame, "Black Skiing, Everyday Racism, and the Racial Spatiality of Whiteness", Journal of Sport and Social Issues, vol. 37, no. 4, 2013, pp. 315-39 [https://doi.org/10.1177/0193723513498607]. Hayden, Dolores, The Power of Place: Urban Landscapes as Public History, 4th edition, Cambridge: The MIT Press, 1997.

Herrera, Luz Marina García, Ma Carmen Díaz Rodríguez, and Alejandro Armas Díaz, "Social Practices and Gender in a Historic Public Space: The Alameda in Santa Cruz de Tenerife (Canary Islands, Spain)", Urban Research \& Practice, vol. 6, no. 2, 2013, pp. 158-73 [https:// doi.org/10.1080/17535069.2013.809913].

Ichwan, Moch Nur, Arskal Salim, and Eka Srimulyani, "Islam and Dormant Citizenship: Soft Religious Ethno-Nationalism and Minorities in Aceh, Indonesia", Islam and Christian-Muslim Relations, vol. 31, no. 2, 2020 , pp. 215-40 [https://doi.org/10.1080/09596410.2020.1780407].

Juris, Jeffrey S., "Reflections on \#Occupy Everywhere: Social Media, 
Stuck in Sharia Space: The Experiences of Christian Students in Langsa

Public Space, and Emerging Logics of Aggregation", American Ethnologist, vol. 39, no. 2, 2012, pp. 259-79 [https://doi.org/10.1111/ j.1548-1425.2012.01362.x].

Lefebvre, Henri, The Production of Space, 1st edition, trans. by Donald Nicholson-Smith, Malden, Mass.: Wiley-Blackwell, 1992.

Makin, Al, "Islamic Acehnese Identity, Sharia, and Christianization Rumor: A Study of the Narratives of the Attack on the Bethel Church in Penauyong Banda Aceh", Journal of Indonesian Islam, vol. 10, no. 1, 2016, pp. 1-36 [https://doi.org/10.15642/JIIS.2016.10.1.1-36].

Nejad, Reza Masoudi, "The Discursive Manifestation of Past and Present Through the Spatial Organization of the Ashura Procession", Space and Culture, vol. 16, no. 2, 2013, pp. 133-60 [https://doi. org/10.1177/1206331213475747].

Nurdin, Abidin et al., "The Role of Ulama in the Application of Islamic Syariah in Aceh: A Study of Aceh Ulama Council's Fatwa on Apostasies and Heresies", Mazahib, vol. 17, no. 1, 2018, pp. 46-68 [https://doi.org/10.21093/mj.v17i1.1022].

Ojo, Matthews A., "Pentecostal Movements, Islam and the Contest for Public Space in Northern Nigeria", Islam and ChristianMuslim Relations, vol. 18, no. 2, 2007, pp. 175-88 [https://doi. org/10.1080/09596410701214043].

Perkins, Alisa, "Muslim Sound, Public Space, and Citizenship Agendas in an American City", Citizenship Studies, vol. 19, no. 2, 2015, pp. 169-83 [https://doi.org/10.1080/13621025.2015.1005948].

Thomsen, Carly, "The Post-Raciality and Post-Spatiality of Calls for LGBTQ and Disability Visibility", Hypatia, vol. 30, no. 1, 2015, pp. 149-66 [https://doi.org/10.1111/hypa.12135].

Yoshimizu, Ayaka, "Chopsticks, Phone Bells and Farms: Fuyuko Taira's Diasporic Spatial Practice", Gender, Place \& Culture, vol. 19, no. 3, 2012, pp. 313-26 [https://doi.org/10.1080/096636 9X.2011.609984].

Zulkarnain, Tgk., "Melihat Lampion Secara Holistik", AJNN.net, https:// www.ajnn.net/news/melihat-lampion-secara-holistik/index.html, accessed 9 Aug 2020. 
Yogi Febriandi \& Yaser Amri 